\title{
PENGARUH KOMPETENSI DAN PENILAIAN PRESTASI KERJA PEGAWAI TERHADAP PROMOSI JABATAN PADA BADAN PENYELENGGARA JAMINAN SOSIAL (BPJS) KESEHATAN CABANG PEMATANGSIANTAR
}

\author{
Oleh: \\ Fikky Chandra Silaban \\ S1 Manajemen \\ Darwin Lie, Marisi Butarbutar, Kartini Harahap
}

Abstraksi

Adapun rumusan masalah penelitian adalah bagaimana pengaruh kompetensi dan penilaian prestasi kerja pegawai terhadap promosi jabatan pada Badan Penyelenggara Jaminan Sosial (BPJS) Kesehatan Cabang Pematangsiantar. Penelitian ini menggunakan desain penelitian kepustakaan dan penelitian lapangan. Populasi berjumlah 41 orang, dan sampel yang digunakan adalah keseluruhan dari populasi. Pengumpulan data dilakukan dengan kuesioner, wawancara, dan dokumentasi. Teknik analisis yang digunakan adalah analisis deskriptif kualitatif, dan analisis deskriptif kuantitatif dengan regresi linier berganda, korelasi dan koefisien determinasi, dan uji hipotesis.

Hasil penelitian dapat disimpulkan sebagai berikut : 1. Kompetensi pegawai sudah sangat baik, penilaian prestasi kerja pegawai sudah baik, dan promosi jabatan sudah baik. 2. Hasil analisis regresi $\hat{Y}=21,407+0,372 X_{1}$ $+0,471 \mathrm{X}_{2}$, artinya terdapat pengaruh positif antara kompetensi pegawai $\left(\mathrm{X}_{1}\right)$ dan penilaian prestasi kerja $\left(\mathrm{X}_{2}\right)$ terhadap promosi jabatan (Y). 3. Hasil analisis korelasi dengan nilai $r=0,630$ terdapat hubungan yang kuat dan positif antara kompetensi dan penilaian prestasi kerja pegawai dengan promosi jabatan. Baik tidaknya promosi jabatan dapat dijelaskan sebesar 39,7\% . 4. Hipotesi $\mathrm{H}_{0}$ ditolak, artinya kompetensi dan penilaian prestasi kerja pegawai berpengaruh positif dan signifikan terhadap promosi jabatan pada Badan Penyelenggara Jaminan Sosial (BPJS) Kesehatan Cabang Pematangsiantar. Adapun saran dari penelitian ini adalah untuk meningkatkan kompetensi pegawai, pihak manajemen personalia memberikan kesempatan bagi pegawai untuk mengikuti pelatihan yang mengarah pada pengembangan kompetensi pegawai. Untuk meningkatkan prestasi kerja pegawai, diperlukan peningkatan produktivitas pegawai. Untuk meningkatkan promosi jabatan maka perlu perbaikan keterampilan prestasi kerja pegawai dalam melaksanakan pekerjaanya.

Kata kunci: Kompetensi, Penilaian Prestasi Kerja Pegawai, dan Promosi Jabatan

\section{Abstraction}

As for this research problem formula is how competency and employee work performance influence to office promotion in Badan Penyelenggara Jaminan Sosial (BPJS) Kesehatan Cabang Pematangsiantar. The research method was done by using design of library research and field research. The population of this research is 41 people, and sample all of us population. Data was collected by questionnaires, interviews, and documentation. The technique of analyzing is descriptive qualitative and descriptive quantitative with double linier regression, coefficient of correlation and determination, and hypothesis test.

The result of this research is : 1. The employee competency has been very good, employee work performance already good, and office promotion already good. 2 . The analyze of regresion is $\hat{Y}=21,407+$ $0,372 X_{1}+0,471 X_{2}$, the means is employee competency $\left(X_{1}\right)$ and employee work performance $\left(X_{2}\right)$ have positive effect to office promotion. 3. Correlation analysis is obtained value of $r=0,630$ it means there is a strong and positive between employee competency and employee work performance with office promotion. Whether or not office promotion can be explained 39,7\%. 4. The hypothesis is $H_{0}$ is rejected, it means the competency and employee work performance have positive and significant in Badan Penyelenggara Jaminan Sosial (BPJS) Kesehatan Cabang Pematangsiantar. The suggestion of this research is to improve the employee competence, the personnel management provides an opportunity for employees to participate in training that leads to the development of employee competencies .To improve the work performance of employees, required an increase in employee productivity. To improve the promotion it needs repair work performance skills of employees in performing their job

Key word: Competency, Employee Work Performance, and Office Promotion.

\section{A. PENDAhuluan}

\section{Latar Belakang Masalah}

Badan Penyelenggara Jaminan Sosial (BPJS) Kesehatan Cabang Pematangsiantar merupakan badan organisasi dan juga perusahaan yang bergerak di bidang pengelolahan asuransi jaminan sosial dan kesehatan di pematangsiantar. Promosi jabatan yang dilaksanakan oleh BPJS Kesehatan Cabang Pematangsiantar diatur oleh kantor pusat BPJS Kesehatan. Adapun jumlah pegawai yang sudah 
pernah mengikuti promosi jabatan sebanyak 73,1\% yaitu sebanyak 30 pegawai dari total 41 pegawai.

Untuk mendukung kegiatan promosi jabatan tersebut, pihak BPJS Kesehatan Cabang Pematangsiantar menetapkan tingkatan kompetensi yang harus dipenuhi setiap pegawai. Adapun kompetensi yang diberlakukan BPJS Kesehatan dalam Keputusan Direksi PT Askes (Persero) Nomor: 602/kep/1210 tentang implementasi Sistem Manajemen Kinerja Pegawai Berbasis Kompetensi (SMKP-BK). Kompetensi tersebut yaitu core competency merupakan kompetensi dasar yang harus dimiliki pegawai dalam dirinya meliputi integritas (integrity), brientasi terhadap pelayanan (customer service rientation), membangun hubungan (relationship building), tingkat kepedulian (managed care), dan berorientasi terhadap prestasi (achievement orientation)

Untuk mendukung segala kegiatan yang telah dilakukan pegawai kepada perusahaan, maka dilakukan penilaian prestasi kerja. Penilaian prestasi kerja pada BPJS Kesehatan Cabang Pematangsiantar berdasarkan Keputusan Direksi PT Askes (Persero) Nomor: 602/Kep/1210 tentang Implementasi SMKP$\mathrm{BK}$ online yang menjunjung tinggi nilai kejujuran dan transparansi, dinilai baik dan tepat karena mencakup hasil kerja yang merupakan pencapaian kerja berdasarkan kuantitas dan kualitas. Kompetensi merupakan pencapaian kompetensi yang dimiliki pegawai. Komitmen merupakan sikap pegawai dalam menyelesaikan tugas yang ada. Tugas tambahan adalah tugas lain diluar tugas pokok yang dapat diselesaikan dengan baik. Kejadian kritis adalah mampu menyelesaikan pekerjaan saat kritis dalam masalah organisasi. Diharapkan penilaian prestasi kerja tepat sasaran dalam hal pengambilan keputusan-keputusan menajerial, salah satunya adalah promosi jabatan pegawai BPJS Kesehatan Cabang Pematangsiantar.

\section{Rumusan Masalah}

a. Bagaimana gambaran kompetensi, penilaian prestasi kerja pegawai dan promosi jabatan pada Badan Penyelenggara Jaminan Sosial (BPJS) Kesehatan Cabang Pematangsiantar.

b. Bagaimana pengaruh kompetensi dan penilaian prestasi kerja pegawai terhadap promosi jabatan pada Badan Penyelenggara Jaminan Sosial (BPJS) Kesehatan Cabang Pematangsiantar baik secara simultan maupun parsial.

\section{Tujuan Penelitian}

a. Untuk mengetahui gambaran kompetensi, penilaian prestasi kerja, dan promosi jabatan pada Badan Penyelenggara Jaminan Sosial (BPJS) Kesehatan Cabang Pematangsiantar.

b. Untuk mengetahui pengaruh kompetensi dan penilaian prestasi kerja pegawai terhadap promosi jabatan pada Badan Penyelenggara Jaminan Sosial (BPJS) Kesehatan Cabang Pematangsiantar baik secara simultan maupun parsial.

\section{Metode Penelitian}

Objek penelitian adalah kantor Badan Penyelenggara Jaminan Sosial (BPJS) Kesehatan Cabang Pematangsiantar Jl. Perintis Pemerdekaan no. 7, Telp. 0622-21088 Fax. 0622-28577, Kecamatan Siantar Barat, Kelurahan Simarito, Kota Pematangsiantar. Populasi adalah semua pegawai Badan Penyelenggara Jaminan Sosial (BPJS) Kesehatan Cabang Pematangsiantar yang berjumlah 41 orang $(\mathrm{N}=41)$.

Desain penelitian adalah Penelitian Kepustakaan (Library Research) dan Penelitian Lapangan (Field Research). Teknik pengumpulan data berupa Kuesioner, Wawancara dan Dokumentasi. Jenis data yang adalah jenis data kualitatif dan data kuantitatif. Hasil data yang diperoleh dari lapangan akan dianalisis secara deskriptif baik bersifat kualitatif dan kuantitatif.

\section{B. LANDASAN TEORI}

1. Manajemen Sumber Daya Manusia

Menurut Mondy (2008:4), manajemen sumber daya manusia merupakan pemanfaatan sejumlah individu untuk mencapai tujuan organisasi. Sedangkan menurut Gomes (2003:6), manajemen sumber daya manusia adalah perencanaan, pengorganisasian, pengarahan, dan pengawasan atas pengadaan, pengembangan, pemberian kompensasi, pengintegrasian, pemeliharaan, dan pemutusan hubungan kerja dengan maksud untuk membantu mencapai tujuan perusahaan, individu, dan masyarakat. Berdasarkan uraian dari beberapa pendapat ahli, dapat disimpulkan manajemen sumber daya manusia adalah salah satu cara dan upaya yang digunakan untuk memanfaatkan tenaga, bakat dan keterampilan manusia untuk mencapai tujuan dan sasaran perusahaan dengan efektif dan efisien.

\section{Kompetensi}

Menurut Mangkunegara (2005:113), mengemukakan bahwa kompetensi merupakan faktor mendasar yang dimiliki seseorang yang mempunyai kemampuan lebih, yang membuatnya berbeda dengan orang yang memiliki kemampuan rata-rata atau biasa saja. Menurut Mathis dan John (2006:219), kompetensi merupakan karateristikkarateristik dasar yang dihubungkan dengan kinerja yang meningkat dari individu-individu atau tim. Berdasarkan uraian pendapat ahli, penulis mengambil kesimpulan bahwa kompetensi adalah karateristik dan kemampuan dasar yang dimiliki seseorang dalam melaksanakan suatu tuntutan pekerjaan dengan keterampilan dan pengetahuan yang dimilikinya.

Menurut Sudarmanto (2009:51), komponenkomponen kompetensi adalah : motive (dorongan), traits (sifat karakter pembawaan), self image (citra diri), dan social role (peran sosial). Sedangkan menurut BPJS Kesehatan (2010:12), kompetensi terbagi tiga kelompok, yaitu kompetensi core, kompetensi role, dan kompetensi functional. Berdasarkan pendapat ahli diatas, maka dapat disimpulkan dalam membangun suatu kompetensi 
didalam diri individu tidak terlepas dari adanya motive, traits (sifat), self image (citra diri), social role (peran sosial), dan didukung dengan adanya pengetahuan, keterampilan, perilaku dan pengalaman yang dimiliki individu yang berkompetensi.

\section{Penilaian Prestasi Kerja}

Menurut Wahyudi (2002:101), penilaian prestasi kerja adalah suatu metode bagi manajemen untuk membuat suatu analisa yang adil dan jujur tentang nilai pegawai bagi organisasi. Sedangkan menurut Panggabean (2002:66), penilaian prestasi kerja merupakan prosedur formal dilakukan dalam organisasi untuk mengevaluasi karyawan dan sumbangan serta kepentingan bagi karyawan. Berdasarkan pendapat ahli di atas, penulis menyimpulkan bahwa penilaian prestasi kerja adalah salah satu cara dalam memperoleh hasil dari kontribusi seorang pegawai, dimana hasil tersebut menjadi sebuah informasi bagi pihak manajemen perusahaan atau organisasi dalam menetapkan keputusan manajerial seperti pemberian kompensasi, promosi jabatan, peningkatan gaji, dan pengembangan karir kedepannya.

Menurut Mangkunegara (2000:67), yang menjadi indikator dalam penilaian prestasi kerja adalah : kerjasama, tanggung jawab, kepemimpinan, dan kedisiplinan. Menurut BPJS Kesehatan Cabang Pematangsiantar, penilaian prestasi kerja berdasarkan Keputusan Direksi PT. Askes (Persero) Nomor: 602/Kep/1210, indikatornya adalah sebagai berikut: hasil kerja, kompetensi, komitmen, tugas tambahan, dan kejadian kritis. Berdasarkan uraian teori diatas, dapat disimpulkan bahwa dalam mengukur pencapaian prestasi kerja dari seorang pegawai dapat digunakan indikator kerja sama, kuantitas dan kualitas pekerjaan, kepemimpinan, kehadiran, dan tanggung jawab dalam menyelesaikan setiap tugas-tugas yang ada di dalam perusahaan dan organisasi.

\section{Promosi Jabatan}

Menurut Siagian (2009:169), promosi jabatan adalah pemindahan pegawai atau karyawan dari satu jabatan atau tempat kepada jabatan atau tempat lebih tinggi serta diikuti dengan tugas, tanggung jawab dan wewenang yang lebih tinggi dari jabatan yang diduduki sebelumnya. Sedangakan menurut Dessler (2007:12), promosi dan pemindahan karyawan adalah bagian yang terintegrasi dari sebagian besar karir seseorang. Berdasarkan uraian teori pendapat ahli diatas, penulis menyimpulkan promosi adalah proses pemindahan jabatan yang diperoleh melalui pertimbangan dari hasil nilai atau pencapaian kinerja seseorang, dan sebagai penghargaan diikuti dengan pemberian tambahan nilai (gaji dan kompensasi lainnya).

Menurut Siagian (2006:169), menjelaskan bahwa yang menjadi dasar promosi jabatan adalah : pengalaman (senioritas), kecakapan (ability), dan kombinasi pengalaman dan kecakapan. Menurut BPJS Kesehatan Cabang Pematangsiantar, adapun dasar promosi jabatan seorang pegawai adalah : prestasi kerja, masa kerja, disiplin, integritas, loyalitas, dan pendidikan. Berdasarkan uraian di atas, penulis menyimpulkan dasar promosi jabatan dalam perusahaan dapat dipertimbangkan dari aspek pengalaman dan kecakapan pegawai, sehingga menghasilkan pencapaian dalam pelaksanaan promosi jabatan yang baik dalam perusahaan.

\section{PEMBAHASAN \\ 1. Analisa}

a. Deskriptif Kualitatif

Analisis deskriptif kualitatif dimaksudkan untuk mendapatkan gambaran atau deskriptif mengenai tanggapan dari konsumen tentang Pengaruh Kompetensi dan Penilaian Prestasi Kerja Pegawai Terhadap Promosi Jabatan pada Badan Penyelenggara Jaminan Sosial (BPJS) Kesehatan Cabang Pematangsiantar. Adapun penetapan kriteria nilai rata-rata jawaban dari responden tersebut dimasukkan ke dalam kelas-kelas interval dengan rumus:

Interval Kelas $=$ Nilai Tertinggi - Nilai Terendah

$$
\begin{aligned}
& =\frac{5-1}{5} \\
& =\frac{4}{5} \\
& =0,8
\end{aligned}
$$

Dari rumus diatas dapat diperoleh interval kelas 0,8 sehingga berlaku ketentuan kategori dengan hasil berikut:

\begin{tabular}{|c|c|c|c|}
\hline \multirow[b]{2}{*}{$\begin{array}{c}\text { Nati } \\
\text { Interval }\end{array}$} & \multicolumn{3}{|c|}{ Karrgani } \\
\hline & $\begin{array}{c}\text { Citra Blerwhipiond } \\
\text { Imaget }\end{array}$ & Kualinas Produh & $\begin{array}{l}\text { Keypeiuszu } \\
\text { Pembellan }\end{array}$ \\
\hline $1,00-1,80$ & Siggr TddESeaju & Sange:Twe Ser- - & 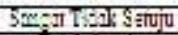 \\
\hline $1.81-2,60$ & Tuth Senüu & Thin 3e-.- & thess=luju \\
\hline $2.61-3.10$ & Culaug Selluju & $\cos 3 x-$ & Cukug S=luju \\
\hline $3.11-1.20$ & Setumu & $3 t .-1-$ & SEluju \\
\hline $5.21-5.00$ & Sered Stemu & 3any. 3e..-- & 3,, 01 SEluju \\
\hline
\end{tabular}

Tabel 1

Nilai Interval dan Kategori Jawaban Responden.

Sumber : hasil pengolahan data

1) Gambaran Kompetensi Pegawai Pada Badan Penyelenggara Jaminan Sosial Kesehatan Cabang Pematangsiantar

Dari hasil analisa, dapat dilihat bahwa pada dimensi core competency indikator pertama mengenai integrity (integritas) yang tinggi terhadap perusahaan diperoleh nilai 4,12 dengan kriteria jawaban baik. Hal ini disebabkan pegawai pegawai sudah memiliki tingkat integritas yang tinggi kepada organisasi dalam melaksanakan tugasnya masingmasing. Selanjutnya pada indikator kedua customer service orientation (berorientasi pada pelayanan) kepada masyarakat diperoleh nilai 4,22 dengan kriteria jawaban sangat baik, disebabkan pegawai memiliki kemampuan dalam melayani masyarakat sebagai tanggung jawab pekerjaan yang ditugaskan pada pegawai. Indikator ketiga mengenai relationship building (membangun hubungan) yang baik dengan rekan kerja dan pimpinan memperoleh nilai 4,27 dengan kriteria jawaban sangat baik. disebabkan perlunya hubungan baik sesama rekan 
kerja dan juga kepada pimpinan sebagai wujud dari kerja sama yang baik dalam meningkatkan kerja sama dalam mencapai tujuan organisasi.

Indikator ke empat mengenai managed care (tingkat kepedulian) kepada pekerjaan, rekan kerja, dan pimpinan memperoleh nilai 4,32 dengan kriteria jawaban sangat baik, disebabkan tingkat kepedulian sangat diperlukan seorang pegawai dalam menjalankan tugasnya, baik kepedulian terhadap pekerjaan, sesama rekan kerja, dan juga kepada pimpinan sehingga tercipta solidaritas yang baik di dalam organisasi. selanjutnya indikator kelima mengenai achievement orientation (orientasi kepada prestasi) pada masing-masing bidang pekerjaan pegawai memperoleh nilai 4,15 dengan kriteria jawaban baik, disebabkan pegawai memiliki kemampuan mencapai sasaran kerja yang menantang dan meningkatkan prestasi kerja yang baik dengan menetapkan sasaran kerja dan berani mengambil resiko.

Pada dimensi role competency, indikator pertama mengenai team leadership (kepemimpinan) pegawai dalam memimpin rekan kerja dalam organisasi memperoleh nilai 4,12 dengan kriteria jawaban baik, disebabkan pegawai memiliki kemampuan sebagai seorang pemimpin didalam organisasi, baik memimpin kelompok kerja, pada saat melakukan diskusi dan pengadaan kerja dilapangan. Pada indikator kedua developing other (mengembangkan orang lain) terhadap pengembangan kemampuan orang lain atau rekan kerja memperoleh nilai 4,34 dengan kriteria jawaban sangat baik. Hal ini disebabkan pegawai memiliki kemampuan untuk memberikan pengaruh besar kepada rekan kerja dalam hal mengembangkan kemampuan individu pegawai lainnya.

Indikator ketiga mengenai conceptual thingking (berpikir konseptual) seorang pegawai dalam pekerjaan, dan pengambilan keputusan memperoleh nilai 4,15 dengan kreiteria jawaban baik. Hal ini disebabkan pegawai memiliki kemampuan dalam melaksanakan tugas dengan menggunakan pemikiran yang sangat kongkrit dan nyata, menggunakan aturan dasar, dan berusaha menciptakan konsep baru untuk mencapai tujuan organisasi. indikator keempat mengenai impact and influence (dampak dan pengaruh) pegawai terhadap rekan kerja, pimpinan dan organisasi memperoleh nilai 4,29 dengan kriteria jawaban sangat baik, disebakan pegawai memiliki kemampuan memberikan dampak dan pengaruh positif bagi rekan kerja lainnya dan juga pimpinan melalui tindakan individu serta menggunakan strategi yang kompleks.

$$
\text { Indikator kelima decision making }
$$
(pengambilan keputusan) yang dilakukan pegawai saat terjadi masalah dalam pekerjaan memperoleh nilai 4,34 dengan kriteria jawaban sangat baik. Hal ini disebabkan pegawai memiliki kemampuan dalam mengambil dan menetapkan keputusan yang telah direncanakan untuk meminimalisir kerugian yang dialami organisasi kedepannya. Indikator keenam yaitu planning and organizing (perencanaan dan pengorganisasian) dalam jangka panjang dan pendek yang dilakukan pegawai memperoleh nilai 4,05 dengan kriteria jawaban baik, disebabkan arti dalam setiap program yang diadakan di Badan Penyelenggara Jaminan Sosial (BPJS) Kesehatan pegawai memiliki kemampuan dalam menyusun perencanaan organisasi yang baik untuk mencapai tujuan yang akan dicapai organisasi.

Pada dimensi functional competency, indikator pertama mengenai business precess (proses bisnis) dari suatu pekerjaan yang dilakukan pegawai yang dapat menghasilkan suatu produk atau layananan memperoleh nilai 4,15 dengan kriteria jawaban baik, yang disebabkan pegawai memang mampu menghasilkan pelayanan yang baik saat melaksanakan tugasnya. indikator selanjutnya yaitu analitycal thinking (pemikiran analitis) kemampuan pegawai dalam memahami masalah/kasus yang berhubungan dengan organisasi memperoleh nilai 4,15 , dengan kriteria jawaban baik, disebabkan setiap pegawai memiliki kemampuan yang baik dalam memahami situasi, masalah yang ditemukan saat bekerja, dan kemampuan menguraikan masalah serta membuat analisa dan perencanaan yang kompleks. Indikator yang ketiga human resource policy and strategy memperoleh nilai 4,32 dengan kriteria jawaban sangat baik, yang disebabkan setiap pegawai memiliki kemampuan dalam membuat perencanaan strategi bagi organisasi, terutama untuk perencanaan sumber daya manusia yang sesuai dengan kebutuhan organisasi.

Indikator yang terakhir mengenai organizing development memperoleh nilai 4,34 dengan kriteria jawaban sangat baik, hal ini disebabkan pegawai memiliki kemampuan yang sangat baik dalam membuat perencanaan/menyusun kerangka kerja yang dapat memperlancar aktivitas dan kegiatan organisasi.

2) Gambaran Penilaian Prestasi Kerja Pada Badan Penyelenggara Jaminan Sosial (BPJS) Kesehatan Cabang Pematangsiantar

Dari hasil analisa, dimensi hasil kerja indikator pertama mengenai pencapaian kuantitas kerja pegawai memperoleh nilai 4,17 dengan kriteria jawaban baik, disebabkan setiap pegawai memiliki target yang telah ditetapkan dari pusat dan menjadi tanggung jawab pegawai. Selanjutnya indikator kedua mengenai pencapaian kualitas kerja pegawai memperoleh nilai 4,05 dengan kriteria jawaban baik, hal ini disebabkan dari pekerjaan yang diselesaikan pegawai memiliki kualitas dan bermanfaat bagi organisasi. pada indikator ketiga mengenai tanggung jawab pegawai terhadap hasil kerja memperoleh nilai 4,12 dengan kriteria jawaban baik. hal ini disebabkan dilihat pegawai memiliki tanggung jawab besar atas tugas yang diberikan, terutama dalam pencapaian target kerja yang diberikan harus terpenuhi, sehingga target organisasi juga terpenuhi.

Kemudian pada dimensi kompetensi indikator pertama mengenai peningkatan kompetensi core pegawai selama bekerja memperoleh nilai 4,05 dengan kriteria jawaban baik. Hal ini disebabkan pegawai dapat memenuhi pencapaian kompetensi 
core yang ditetapkan organisasi. Indikator selanjutnya mengenai peningkatan kompetensi role pegawai selama bekerja memperoleh nilai 4,05 dengan kriteria jawaban baik. hal ini disebabkan pegawai dapat memenuhi pencapaian kompetensi role yang ditetapkan organisasi. Indikator ketiga mengenai peningkatan kompetensi functional memperoleh nilai 4,22 dengan kriteria jawaban sangat baik. Hal ini disebabkan pegawai telah memenuhi pencapaian kompetensi functional yang telah ditetap organisasi.

Pada dimensi komitmen indikator pertama mengenai komitmen pegawai untuk setia kepada pekerjaan dan organisasi memperoleh nilai 4,05 dengan kriteria jawaban baik. hal ini disebabkan pegawai memiliki komitmen yang sangat baik dalam memegang tanggung jawab pekerjaan yang dibebankan kepada pegawai. indikator selanjutnya mengenai kemauan pegawai untuk melakukan lembur diluar jam kerja normal memperoleh nilai 4,02 dengan kriteria jawaban baik, disebabkan pegawai memiliki kemauan dalam melakukan kerja lembur, apabila ada pekerjaan yang dituntut organisasi penyelesaiannya lebih cepat dari yang telah ditetapkan. kemudian indikator selanjutnya mengenai rasa bangga pegawai terhadap organisasi memporel nilai 4,00 dengan kriteria jawaban baik. Hal ini disebabkan organisasi memberikan jaminan karir yang baik bagi pegawai, gaji yang baik, serta kesempatan promosi yang baik.

Selanjutnya pada dimensi tugas tambahan indikator pertama mengenai respon pegawai ketika mendapatkan tugas tambahan dari pimpinan memperoleh nilai 3,95 dengan kriteria jawaban baik. Hal ini disebabkan oleh pegawai tidak menolak tugas tambahan yang diberikan, karena tugas tambahan akan memberi nilai tambah bagi prestasi kerja pegawai. indikator selanjutnya mengenai dampak pemberian tugas tambahan yang diberlakukan organisasi kepada pegawai memperoleh nilai 4,00 dengan kriteria jawaban baik. Hal ini disebakan pemberian tugas tambahan akan mempengaruhi pinilaian prestasi kerja pegawai kedepannya. selanjutnya pada indikator mengenai tanggung jawab pegawai terhadap tugas tambahan yang diberikan memperoleh nilai 4,05 dengan kriteria jawaban baik. Hal ini disebabkan pegawai memiliki tanggung jawab penuh dalam menyelesaikan tugas tambahan yang diberikan.

Selanjutnya pada dimensi kejadian kritis indikator pertama mengenai kemampuan pegawai dalam menyelesaikan pekerjaan disaat kejadian kritis memperoleh nilai 4,12 dengan kriteria jawaban baik, disebabkan pegawai memiliki kemempuan dalam menyelesaikan tugas tepat waktu disaat keadaan kristis dalam organisasi. indikator selanjutnya mengenai tindakan yang ditunjukkan pegawai dalam menghadapi kejadian kritis memperoleh nilai 4,17 dengan kriteria jawaban baik. Hal ini disebabkan pegawai memberikan respon dan tindakan yang baik dalam menghadapi kejadian kritis. indikator terakhir mengenai ketepatan keputusan yang diambil pegawai terhadap kejadian kritis yang ada memperoleh nilai
4,15 dengan kriteria jawaban baik, disebabkan pegawai mampu menetapkan keputusan yang diambil dan tidak merugikan organisasi.

\section{3) Gambaran Promosi Jabatan Pada Kantor Badan Pelayanan Jaminan Sosial (BPJS) \\ Kesehatan Cabang Pematangsiantar}

Dari hasil analisa, dapat dilihat bahwa dimensi hasil kerja indikator pertama mengenai prestasi kerja pegawai menjadi pertimbangan terhadap pengembangan karir kedepannya memperoleh nilai 3,95, dengan kriteria jawaban baik, disebabkan untuk menjamin suatu posisi dalam organisasi pegawai harus meningkatkan prestasi kerjanya agar dapat mendapatkan kesempatan promosi kejenjang yang lebih tinggi. Indikator selanjutnya mengenai pegawai dituntut memiliki keterampilan yang baik sesuai pekerjaan dan posisi jabatannya, memperoleh nilai 4,00 dengan kriteria jawaban baik, disebabkan dalam menduduki suatu posisi di organisasi tentunya memiliki tingkat kesulitan pekerjaan yang beragam, maka diperlukan keterampilan yang sesuai dengan bidang yang ditekuni pegawai supaya pekerjaan dapat dikuasai dengan baik.

Pada indikator ketiga mengenai hasil kerja yang dicapai pegawai dapat membantu pencapaian target organisasi memperoleh nilai4,15, dengan kriteria jawaban baik. hal ini disebabkan hasil kerja yang dibebankan kepada pegawai dalam bentuk target yang harus dicapai. Apabila target pekerjaan pegawai tercapai maka secara otomatis target yang ditetapkan kepada Badan Penyelenggara Jaminan Sosial (BPJS) Kesehatan Cabang Pematangsiantar terpenuhi. Indikator selanjutnya dapat dilihat pada dimensi masa kerja yaitu indikator mengenai pegawai yang memiliki pengalaman kerja layak untuk dipromosikan memperoleh nilai 4,07 dengan kriteria jawaban baik, disebabkan pegawai yang berpengalaman dalam bekerja dan mengetahui tingkat kesulitan pekerjaan, maka pekerjaan tersebut akan mudah diselesaikan.

Indikator selanjutnya menegenai pegawai yang memiliki masa kerja yang lebih lama lebih diutamakan untuk dipromosikan memperoleh nilai 4,22 dengan kriteria jawaban sangat baik, disebabkan masa kerja yang lebih lama tentunya membuat pegawai lebih memiliki pengalaman yang lebih banyak dibandingkan dengan pegawai yang meiliki masa kerja yang sedikit, akan tetapi pada Badan Penyelenggara Jaminan Sosial (BPJS) Kesehatan Cabang Pematangsiantar masa kerja tidak menjadi prioritas, melainkan faktor pendukung dalam promosi. Selanjutnya indikator mengenai pegawai harus memiliki penguasaan yang baik terhadap pekerjaan memperoleh nilai 4,00 dengan kriteria jawaban baik, disebabkan penguasaan pekerjaan akan memudahkan pegawai dalam menyelesaikan tugas-tugas yang diberikan sehingga tugas cepat terselesaikan dan target tercapai.

Indikator selanjutnya dapat dilihat pada dimensi integritas yaitu indikator mengenai pegawai yang memiliki kesetiaan yang tinggi kepada 
organisasi layak dipromosikan, memperoleh nilai 4,15 dengan kriteria jawaban baik, disebabkan kesetiaan sangat diperlukan suatu organisasi agar bisa mempertahankan pegawai yang berkualitas, dengan adanya kesetiaan terhadap organisasi akan membantu proses pengembangan organisasi kedepannya.

Indikator selanjutnya mengenai pegawai dituntut memiliki tingkat tanggung jawab yang tinggi terhadap pekerjaan dan organisasi, memperoleh nilai 4,12 dengan kriteria jawaban baik, disebabkan pegawai yang bertanggung jawab akan mempertanggung jawabkan semua hasil kerjanya baik hasil yang didapat buruk dan hasil yang didapat baik. hal ini untuk mencegah terjadi kecurangan yang dilakukan pegawai selama bekerja.selanjutnya pada indikator pegawai harus memiliki sikap jujur dan terbuka selama melakukan pekerjaan memperoleh nilai 4,15, dengan kriteria jawaban baik. Hal ini disebabkan dalam setiap pelaksanaan tugas baik dikantor dan dilapangan diperlukan kejujuran dalam menyampaikan hasil laporan kerja tanpa adanya sesuatu yang ditutupi yang mengakibatkan organisasi rugi.

Indikator berikut mengenai pegawai harus hadir tepat waktu dapat dilihat pada dimensi disiplin yang memperoleh nilai yaitu 4,15 dengan kriteria jawaban baik, disebabkan pegawai yang hadir tepat waktu menunjukkan sikap disiplin terhadap waktu jam kerja. Indikator selanjutnya mengenai absensi kehadiran sangat penting bagi pegawai memperoleh nilai 4,22 dengan kriteria jawaban sangat baik. Hal ini disebabkan kehadiran seorang pegawai dapat mempengaruhi prestasi kerja dan hasil kerjanya. Indikator selanjutnya yaitu pegawai harus disiplin saat melakukan kegiatan atau pekerjaan (memiliki tanggung jawab, memakai pakaian dinas, tanda pengenal, dan menaati peraturan yang ada) memperoleh nilai 4,07 dengan kriteria jawaban baik. Hal ini disebabkan dilihat dilapangan selama melakukan penelitian bahwa setiap pegawai selalu memakai pakaian dinas, tanda pengenal dan mematuhi setiap peraturan yang ada sebagai wujud dari pegawai yang memiliki teladan yang baik.

Pada dimensi loyalitas terdapat indikator mengenai organisasi yang menuntut loyaltas yang tinggi untuk pertimbangan promosi memperoleh nilai 4,22 dengan kriteria jawaban baik. Hal ini disebabkan pegawai yang memiliki loyalitas yang tinggi menunjukkan kesetiaan kepada organisasi, begitu pula dengan pegawai Badan Penyelenggara Jaminan Sosial (BPJS) Kesehatan Cabang Pematangsiantar memiliki loyalitas yang tinggi dengan setia kepada pekerjaan dan organisasi.

Indikator selanjutnya mengenai pegawai wajib menjaga kerahasiaan organisasi dari pihak luar memperoleh nilai 4,07 dengan kriteria jawaban baik, disebabkan sistem kerahasian milik organisasi merupakan kunci dari sukses organisasi tersebut, apabila rahasia organisasi terbongkar maka organisasi akan mengalami masalah yang cukup fatal. Indikator berikut mengenai pegawai yang loyal harus mematuhi peraturan dan kode etik yang berlaku serta mengamalkannya memperoleh nilai 4,15 dengan kriteria jawaban baik, disebabkan kode etik selalu diucapkan pegawai saat masuk jam kantor dan memulai briefing.

Pada dimensi pendidikan indikator pegawai dengan tingkat pendidikan yang lebih tinggi diutamakan untuk promosi jabatan memperoleh nilai 4,07 dengan kriteria jawaban baik, disebabkan pendidikan sangat mempengaruhi kedudukan pegawai di organisasi dan juga jenis pekerjaan yang diberika. Pada Badan Penyelenggara Jaminan Sosial (BPJS) Kesehatan Cabang Pematang Siantar ratarata pegawai memiliki tingkat pendidikan sarjana, dan ada juga yang melanjutkan pendidikan kejenjang yang lebih tinggi. Indikator selanjutnya yaitu untuk menduduki suatu jabatan kualifikasi pendidikan sangat diperlukan penyesuaiannya memperoleh nilai 3,95 dengan kriteria jawaban baik. Hal ini disebabkan setiap posisi yang terdapat pada Badan Penyelenggara Jaminan Sosial (BPJS) Kesehatan Cabang Pematangsiantar disesuaikan dengan pendidikan dan kehlian yang didapat pegawai. Dan indikator terakhir mengenai promosi jabatan disesuai dengan pendidikan formal yang dimiliki pegawai memperoleh nilai 4,07 dengan kriteria jawaban baik, disebabkan promosi jabatan yang diadakan juga melihat tingkat pendidikan yang dimiliki pegawai yang nantinya akan disesuaikan dengan posisi yang akan diduduki.

\section{b. Deskriptif Kuantitatif \\ 1) Regresi Linear Berganda}

Analisis linier berganda digunakan untuk mengetahui pengaruh variabel bebas $(\mathrm{X})$ dan variabel terikat $(\mathrm{Y})$, dimana $\mathrm{X}_{1}$ adalah kompetensi, $\mathrm{X}_{2}$ adalah penilaian prestasi kerja, dan $\mathrm{Y}$ adalah promosi jabatan. Maka dilakukan perhitungan menggunakan program aplikasi SPSS versi 20 dengan hasil hitung regresi sebagai berikut:

Tabel 2

Hasil Regresi Linier Berganda Coefficients $^{\mathrm{a}}$

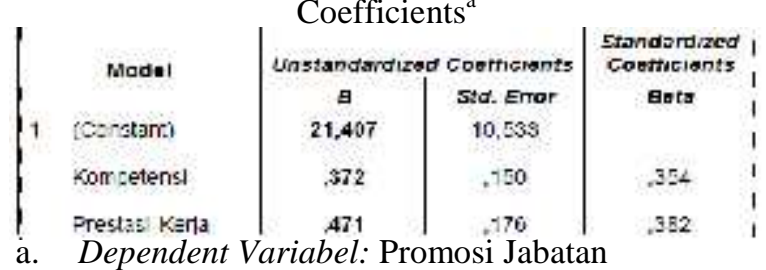

Dependent Variabel: Promosi Jabatan

Sumber: hasil pengolahan data dengan SPSS versi 20

Berdasarkan tabel 2 di atas hasil analisis regresi dengan SPSS versi 20 pada tabel 16 diatas diperoleh $\hat{Y}=21,407+0,372 X_{1}+0,471 X_{2}$, artinya terdapat pengaruh positif antara variabel bebas kompetensi $\left(\mathrm{X}_{1}\right)$ dan penilaian prestasi kerja $\left(\mathrm{X}_{2}\right)$ terhadap promosi jabatan (Y) pada Badan Penyelenggara Jaminan Sosial (BPJS) Kesehatan Cabang Pematangsiantar.

\section{2) Analisis Korelasi dan Koefisien Determinasi} Berikut ini hasil kefisien korelasi dan koefisien determinasi antara variabel bebas kompetensi (X1) dan penilaian prestasi kerja (X2) dengan variabel terikat promosi jabatan (Y). Dengan 
bantuan program SPSS versi 20, didapatkan hasil perhitungan koefisien korelasi sebagai berikut:

Tabel 3

Hasil Koefisien Korelasi dan Determinasi

\begin{tabular}{|c|c|c|c|c|}
\hline \multicolumn{5}{|c|}{ Model Summary } \\
\hline Model & $\mathbf{R}$ & R Square & Agliust $R$ Squere & $\begin{array}{l}\text { Sid. Error of the } \\
\text { Estimare }\end{array}$ \\
\hline 1 & .6304 & 397 & 365 & 4.70 \\
\hline
\end{tabular}

Predictors: (Constant), Kompetensi, Penilaian

Prestasi Kerja

b. Dependent Variabel: Promosi Jabatan

Sumber: hasil pengolahan data dengan SPSS versi 20 Berdasarkan hasil analisis pada tabel 3 di atas diperoleh nilai $\mathrm{r}=0,630$, yang artinya terdapat hubungan yang kuat dan positif antara kompetensi dan penilaian prestasi kerja dengan promosi jabatan pada Badan Penyelenggara Jaminan Sosial (BPJS) Kesehatan Cabang Pematangsiantar. Kemudian diperoleh nilai koefisien determinasi R Square 0,397, artinya baik tidaknya promosi jabatan dapat dijelaskan sebesar $39,7 \%$ oleh kompetensi dan penilaian prestasi kerja, selebihnya $60,3 \%$ dijelaskan oleh faktor-faktor lain seperti loyalitas, disiplin, pendidikan dan lain-lain yang tidak dibahas dalam penelitian ini.

\section{3) Uji Hipotesis}

\section{a) Uji Simultan (Uji F)}

Uji $\mathrm{F}$ digunakan untuk menguji pengaruh variabel bebas terhadap variabel terikat secara bersama-sama atau keseluruhan. Pengujian hipotesi ini dilakukan dengan kriteria pengujian jika $\mathrm{F}_{\text {hitung }}>$ $\mathrm{F}_{\text {tabel}}$, atau signifikansi $\leq \alpha 0,05$ maka $\mathrm{H}_{0}$ di tolak. Pengujian ini menggunakan bantuan SPSS versi 20, didapatkan hasil perhitungan $\mathrm{F}_{\text {hitung }}$ sebagai berikut: Tabel 4

Hasil Uji Simultan (Uji F)

\begin{tabular}{|c|c|c|c|c|c|c|}
\hline & & & No & & & \\
\hline & Model & $\begin{array}{l}\text { Sum or } \\
\text { Square }\end{array}$ & df & $\begin{array}{l}\text { Mean } \\
\text { Square }\end{array}$ & $\mathbf{F}$ & $\boldsymbol{E s}_{\text {g. }}$ \\
\hline 7 & 17mgmasion & $4+2, S 12:$ & $\geqslant$ & 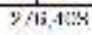 & 92,501 &, $0000^{h}$ \\
\hline & |fe:s:atai| & s.t: yis & 38 & 2) 117 & & \\
\hline & Tcta & 1398,024 & 40 & & & \\
\hline
\end{tabular}

a. Dependent Variabel: Promosi Jabatan

b. Predictors: (Constant), Kompetensi, Penilaian Prestasi Kerja

Sumber: hasil pengolahan data dengan SPSS versi 20

Berdasarkan tabel 4 hasil pengujian secara simultan dengan nilai $F_{\text {hitung }}$ sebesar 12,501, $>F_{\text {tabel }}$ dengan $\mathrm{df}=\mathrm{n}-\mathrm{k}-1(41-2-1=38)$ sebesar 3,24 atau

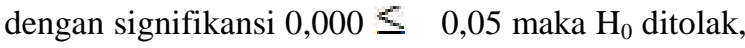
artinya kompetensi dan penilaian prestasi kerja berpengaruh positif dan signifikan terhadap promosi jabatan pada Badan Penyelenggara Jaminan Sosial (BPJS) Kesehatan Cabang Pematangsiantar.

\section{b) Uji Parsial (Uji t)}

Uji $\mathrm{t}$ digunakan untuk menguji pengaruh variabel bebas terhadap variabel terikat secara parsial. Pengujian ini dilakukan dengan kriteria pengujian, jika $t_{\text {hitung }}>t_{\text {tabel }}$, atau signifikansi $\leq \alpha 0,05$ maka $\mathrm{H}_{0}$ di tolak. Pengujian ini menggunakan bantuan SPSS versi 20, di dapat hasil perhitungan Uji t sebagai berikut :
Tabel 5

Perkiraan Nilai $t_{\text {hitung }}$ Coefficients $^{\mathrm{a}}$

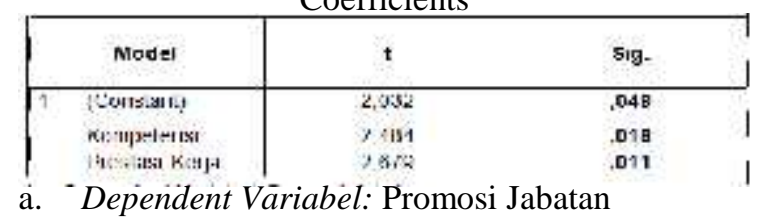

Sumber: hasil pengolahan data dengan SPSS versi 20

Berdasarkan tabel 5 uji hipotesis secara parsial diatas (Uji $t$ ), diperoleh nilai $t_{\text {hitung }}$ pada variabel kompetensi $\left(\mathrm{X}_{1}\right)$ sebesar 2,484 $>\mathrm{t}_{\text {tabel }}$ dengan $\mathrm{df}=\mathrm{n}-\mathrm{k}-1(41-2-1=38)$ sebesar 2,024, atau dengan taraf signifikan $0,018 \leq \alpha 0,05$ maka $\mathrm{H}_{0}$ ditolak, artinya kompetensi berpengaruh positif dan signifikan terhadap promosi jabatan pada Badan Penyelenggara Jaminan Sosial (BPJS) Kesehatan Cabang Pematangsiantar. Kemudian pada variabel penilaian prestasi kerja $\left(\mathrm{X}_{2}\right)$ diperoleh nilai $\mathrm{t}_{\text {hitung }}$ sebesar 2,679 $>\mathrm{t}_{\text {tabel }}$ dengan $\mathrm{df}=\mathrm{n}-\mathrm{k}-1(41-2-1=$ 38) sebesar 2,024, atau dengan taraf signifikan 0,011 $\leq \alpha 0,05$ maka $\mathrm{H}_{0}$ ditolak, artinya penilaian prestasi kerja berpengaruh positif dan signifikan pada Badan Penyelenggara Jaminan Sosial (BPJS) Kesehatan Cabang Pematangsiantar.

\section{Evaluasi}

\section{a. Kompetensi Pegawai Pada Badan} Penyelenggara Jaminan Sosial (BPJS)

\section{Kesehatan Cabang Pematangsiantar}

Pada dimensi core competency indikator integrity (integritas), pegawai memiliki integritas yang tinggi terhadap perusahaan memperoleh nilai sebesar 4,12 yang memang tidak jauh dari nilai ratarata. Cara memperbaiki agar pegawai memiliki integritas yang tinggi kepada perusahaan yaitu meningkatkan kualitas kerja pegawai, dan meningkatkan nilai kejujuran dan bersikap positif saat bekerja

Pada indikator achievement orientation (berorientasi pada prestasi), pegawai memiliki pencapaian prestasi dibidangnya sendiri dengan nilai 4,15 dengan kriteria jawaban baik. cara meningkatkanya adalah mendorong pegawai dengan memberikan motivasi untuk lebih meningkatkan kuantitas dan kualitas kerjanya sesuai dengan target yang telah disepakati. Kemudian pada dimensi role competency indikator team leadership (kepemimpinan), pegawai memiliki kemampuan memimpin rekan kerja didalam organisasi dengan nilai 4,12. Cara mengoptimalkannya adalah dengan memberikan kesempatan lebih kepada pegawai dalam melatih dirinya memimpin sebuah kelompok kerja dengan tujuan melatih jiwa kepemimpinan pegawai. Pada indikator selanjutnya yaitu conceptual thinking (berpikir konseptual) pegawai dalam melaksanakan pekerjaan dan pengambilan keputusan diperlukan pemikiran konsep yang matang memperoleh nilai 4,15. Adapun cara untuk meningkatkannya adalah memberikan pegawai tugas-tugas yang memerlukan kemampuan pegawai dalam hal pemahan pekerjaan dengan mengandalkan 
pemikiran yang konsep serta mampu mengambil keputusan yang tepat.

Indikator selanjutnya yaitu planning and organizing (perencanaan dan pengorganisasian), pegawai mampu membuat rencana pengorganisasian yang baik dalam waktu jangka pendek dan jangak panjang memperoleh nilai 4,05. Adapun cara untuk memperbaikinya adalah pagawai harus lebih baik lagi menyusun sendiri suatu perencanaan dan juga pengorganisasian yang baik lagi untuk pekerjaannya dan juga untuk organisasi.

Pada dimensi functional competency indikator business process, pegawai dapat menghasilkan suatu produk yang bernilai positif untuk mencapai tujuan organisasi memperoleh nilai 4,15. Adapun cara meningkatkan indikator ini yaitu menghimbau pegawai untuk meningkatkan kualitas kerja dan juga keterampilan pegawai dalam bekerja. Indikator selanjutnya yaitu analitycal thinking yang dimiliki pegawai mampu menganalisis kasus, permasalahan yang berhubungan dengan pekerjaan dan organisasi dengan nilai 4,15. Cara meningkatkanya adalah dengan memberikan kesempatan kepada pegawai untuk ikut dalam menyelesaikan permasalahan yang ada dalam organisasi sehingga pegawai memiliki kebiasaan dan juga kemampuan dalam menyelasaikan kasus-kasus selanjutnya.

\section{b. Penilaian Prestasi Kerja Pegawai Pada Badan Penyelenggara Jaminan Sosial (BPJS) \\ Kesehatan Cabang Pematangsiantar}

Pada dimensi hasil kerja indikator pencapaian kualitas kerja pegawai dengan nilai 4,05. Adapun cara meningkatkannya adalah pimpinan menghimbau pegawai, dalam mencapai target kerja yang dicapai bukan hanya kuantitas tetapi juga meningkatkan kualitas kerja, agar pekerjaan memiliki nilai tambah. Indikator selanjutnya adalah peningkatan kompetensi core pegawai selama bekerja dengan nilai 4,05. Cara memperbaikinya adalah pimpinan menghimbau pegawai agar meningkatkan kategori kompetensi core yang belum dicapai pegawai. Selanjutnya indikator peningkatan kompetensi role pegawai dengan nilai 4,05. Cara meningkatkannya yaitu pimpinan menghimbau pegawai agar meningkatkan atau melengkapi kompetensi role yang belum tercapai. Pada dimensi selanjutnya yaitu komitmen indikator komitmen pegawai untuk setia kepada pekerjaan dan organisasi dengan nilai 4,05. Cara memperbaiki dan meningkatkannya adalah organisasi memberikan perhatian lebih akan kebutuhan pekerjaan pegawai sehingga pegawai memiliki tingkat kepedulian yang tinggi kepada organisasi dan pekerjaannya.

Indikator selanjutnya mengenai kemauan pegawai untuk melakukan tugas lembur diluar jam kerja dengan nilai 4,02. Cara memperbaikinya yaitu pimpinan tidak memaksakan pegawai dalam menyediakan waktu luangnya dalam melakukan lembur, tetapi membiarkan pegawai sepenuhnya untuk mengambil ahli pekerjaannya, sehingga disaat organisasi menginginkan target tercapai dalam waktu dekat maka pegawai akan memiliki kemauan sendiri dalam melakukan lembur diluar jam kerja yang diberikan. Indikator selanjutnya mengenai rasa bangga pegawai terhadap organisasi dengan nilai 4,00. Cara memperbaikinya adalah organisasi dan juga pimpinan memberikan perhatian lebih akan kebutuhan dan keinginan pegawai dalam bekerja, memberikan kesempatan bebas berpendapat dan bekarya dalam bekerja.

Pada dimensi selanjutnya yaitu indikator mengenai respon pegawai ketika mendapat tugas tambahan dari pimpinan dengan nilai 3,95 yang jauh dari nilai rata-rata. Cara memperbaikinya yaitu menghimbau pegawai agar tidak mengabaikan tugas tambahan yang diberikan, dikarenakan tugas tambahan memiliki nilai tambah bagi penilaian prestasi kerja pegawai. Indikator selanjutnya dampak pemberian tugas tambahan yang diberlakukan organisasi kepada pegawai dengan nilai 4,00. Cara memperbaikinya tugas tambahan yang diberikan oleh pimpinan dan organisasi harus mengarah tepat dan sesuai dengan bidang pekerjaan pegawai agar memberikan dampak positif bagi pegawai. Indikator terkhir mengenai tanggung jawab pegawai terhadap tugas tambahan yang diberikan dengan nilai 4,05. Cara meningkatkannya adalah pegawai menyelesaikan tugas tambahan yang diberikan sesuai dengan waktu yang diberikan dengan hasil yang dapat dipertanggung jawabkan.

\section{c. Promosi Jabatan Pada Badan Penyelenggara Jaminan Sosial (BPJS) Kesehatan Cabang Pematangsiantar}

Pada dimensi hasil kerja indikator prestasi kerja pegawai menjadi pertimbangan terhadap pengembangan karir pegawai kedepannya mendapat nilai 3,95. Cara meningkatkannya hal tersebut yaitu pegawai harus lebih meningkatkan prestasi kerja baik kuantitas dan kualitasnya. Indikator selanjutnya pegawai dituntut memiliki keterampilan yang baik sesuai pekerjaan dan posisi jabatannya dengan nilai 4,00. Cara meningkatkannya yaitu memberikan kesempatan bagi pegawai meningkatkan keterampilan dalam bekerja sehingga penguasaan tugas yang diberikan akan lebih mudah diselesaikan.

Pada dimensi masa kerja indikator mengenai pegawai yang memiliki pengalaman kerja layak untuk dipromosikan dengan nilai 4,07. Cara meningkatkannya yaitu pimpinan memberikan tugastugas yang bisa meningkatkankan pengalaman kerja pegawai, baik tugas luar dan tugas didalam organisasi. indikator selanjutnya mengenai pegawai harus memiliki penguasaan yang baik terhadap pekerjaan dengan nilai 4,00. Cara meningkatkannya memberika pegawai pelatihan dalam menyelesaikan tugas-tugas baru sehingga menambah pengetahuan pegawai dalam menguasai pekerjaan yang dikerjakan pegawai.

Pada dimensi disiplin indikator pegawai harus disiplin saat melakukan kegiatan/pekerjaan (seperti tanggung jawab, memakai pakaian dinas, tanda pengenal, dan menaati peraturan yang ada) dengan nilai 4,07. Cara meningkatkannya adalah pimpinan menghimbau pegawai selalu berpakaian dinas saat 
bekerja, menggunakan tanda pengenal, dan mematuhi kode etik demi menjaga nama baik organisasi. selanjutnya pada dimensi loyalitas indikator pegawai wajib menjaga kerahasiaan organisasi dari pihak luar dengan nilai 4,07. Cara meningkatkannya adalah pimpinan selalu memberikan pengarahan kepada pegawai agar selalu menjaga nama baik perusahaan, mematuhi kode etik, dan tidak membeberkan file yang bersifat rahasia yang dapat merugikan organisasi dan seluruh stakeholder yang didalam organisasi.

Pada dimensi pendidikan indikator pegawai dengan tingkat pendidikan yang lebih tinggi lebih diutamakan untuk promosi jabatan memperoleh nilai 4,07. Cara meningkatkan hal tersebut adalah mempeberikan kesempatan bagi pegawai yang masih memiliki tingkat pendidikan rendah melanjutkan pendidikannya ketingkat yang lebih tinggi. Indikator selanjutnya adalah untuk menduduki suatu jabatan kualifikasi pendidikan sangat diperlukan penyesuaiannya dengan nilai 3,95. Adapun cara memperbaikinya adalah pihak manajemen personalia melaksanakan ujian kepada pegawai terhadap bidang pekerjaan yang akan diambil sesuai dengan jurusan pendidikan yang dimiliki, sehingga tidak terjadi kesalahan dalam penempatan posisi kerja. Indikator terakhir adalah promosi jabatan disesuaikan dengan pendidikan formal yang dimiliki pegawai dengan nilai 4,07. Cara memperbaiki dan meningkatkannya adalah pihak personalia dalam melakukan kegiatan promosi harus menyesuaikan tingkat pendidikan terhadap bidang pekerjaan dan posisi pekerjaan yang diambil, agar tidak terjadi penyimpangan posisi jabatan.

\section{KESIMPULAN DAN SARAN}

\section{Kesimpulan}

a. Hasil analisis deskriptif kualitatif tentang kompetensi pegawai pada Badan Penyelenggara Jaminan Sosial (BPJS) Kesehatan Cabang Pematangsiantar, dari total jawaban responden mengenai kompetensi pegawai berdasarkan indikator-indikator yang terdapat pada setiap dimensi memperoleh nilai rata-rata 4,22 dengan kategori sangat baik. kemudian yang mendapatkan nilai rata-rata tertinggi yaitu 4,34 pada dimensi role competency indikator, dan functional competency indikator. sedangkan untuk yang mendapat nilai rata-rata terendah yaitu 4,05 terdapat pada dimensi role competency.

b. Hasil analisis deskriptif kualitatif tentang promosi jabatan pada Badan Penyelenggara Jaminan Sosial (BPJS) Kesehatan Cabang Pematangsiantar, dari total jawaban responden mengenai penilaian prestasi kerja pegawai, keseluruhannya mendapat nilai rata-rata 4,08 . Adapun jawaban dengan nilai rata-rata tertinggi dengan nilai 4,22 pada dimensi kompetensi. Sedangkan untuk nilai jawaban terendah dengan nilai 3,95 terdapat pada dimensi tugas tambahan.

c. Hasil analisis deskriptif kualitatif mengenai promosi jabatan pada Badan Penyelenggara
Jaminan Sosial (BPJS) Kesehatan Cabang Pematangsiantar, maka dapat disimpulkan bahwa indikator-indikator promosi jabatan dinilai dengan rata-rata 4,10 dengan kiriteria jawaban baik. Adapun dengan jawaban nilai rata-rata tertinggi dengan nilai 4,22 pada dimensi disiplin. Sedangkan jawaban dengan nilai rata-rata terendah dengan nilai 3,95 pada dimensi hasil kerja dan pendidikan. Maka promosi jabatan dapat dikatakan baik, dilihat dari hasil jawaban rata-rata responden.

d. Hasil analisis regresi linier berganda diperoleh $\hat{Y}$ $=21,407+0,372 X_{1}+0,471 X_{2}$, artinya terdapat pengaruh positif antara variabel bebas kompetensi pegawai $\left(\mathrm{X}_{1}\right)$ dan penilaian prestasi kerja $\left(\mathrm{X}_{2}\right)$ terhadap promosi jabatan $(\mathrm{Y})$ pada Badan Penyelenggara Jaminan Sosial (BPJS) Kesehatan Cabang Pematangsiantar.

e. Hasil analisis korelasi diperoleh nilai $r=0,630$, yang artinya terdapat hubungan yang kuat dan positif antara kompetensi dan penilaian prestasi kerja dengan promosi jabatan pada Badan Penyelenggara Jaminan Sosial (BPJS) Kesehatan Cabang Pematangsiantar. Kemudian diperoleh nilai koefisien determinasi R Square 0,397, artinya baik tidaknya promosi jabatan dapat dijelaskan sebesar 39,7\% oleh kompetensi dan penilaian prestasi kerja, selebihnya $60,3 \%$ dijelaskan oleh faktor-faktor lain seperti loyalitas, disiplin, pendidikan dan lain-lain yang tidak dibahas dalam penelitian ini.

f. Hasil pengujian secara simultan dengan nilai $\mathrm{F}_{\text {hitung }}$ sebesar 12,501, $>\mathrm{F}_{\text {tabel }}$ dengan $\mathrm{df}=\mathrm{n}-\mathrm{k}-1$ $(41-2-1=38)$ sebesar 3,24 atau dengan signifikansi $0,000 \mathrm{~S} \alpha 0,05$ maka $\mathrm{H}_{0}$ ditolak, artinya kompetensi dan penilaian prestasi kerja berpengaruh positif dan signifikan terhadap promosi jabatan pada Badan Penyelenggara Jaminan Sosial (BPJS) Kesehatan Cabang Pematangsiantar.

g. Hasil uji hipotesi secara parsial diatas (Uji t), diperoleh nilai $t_{\text {hitung }}$ pada variabel kompetensi $\left(\mathrm{X}_{1}\right)$ sebesar 2,484 $>\mathrm{t}_{\text {tabel }}$ dengan $\mathrm{df}=\mathrm{n}-\mathrm{k}-1$ (41 $2-1=38$ ) sebesar 2,024, atau dengan taraf signifikan $0,018 \leq \alpha 0,05$ maka $\mathrm{H}_{0}$ ditolak, artinya kompetensi berpengaruh positif dan signifikan terhadap promosi jabatan pada Badan Penyelenggara Jaminan Sosial (BPJS) Kesehatan Cabang Pematangsiantar. Kemudian pada variabel penilaian prestasi kerja $\left(\mathrm{X}_{2}\right)$ diperoleh nilai $t_{\text {hitung }}$ sebesar 2,679 $>t_{\text {tabel }}$ dengan $d f=n-k-$ $1(41-2-1=38)$ sebesar 2,024 , atau dengan taraf signifikan $0,011 \leq \alpha 0,05$ maka $\mathrm{H}_{0}$ ditolak, artinya penilaian prestasi kerja berpengaruh positif dan signifikan pada Badan Penyelenggara Jaminan Sosial (BPJS) Kesehatan Cabang Pematangsiantar.

\section{Saran}

a. Agar kompetensi pegawai dapat terpenuhi dengan baik maka perlu dilakukan perbaikan berdasarkan hasil evaluasi yaitu pada dimensi 
core competency indikator intgritas (integrity), indikator orientasi kepada prestasi (achievement orientation), kemudian pada dimensi role competency indikator kepemimpinan (team leadership), selanjutnya indikator pengambilan keputusan (decision making), kemudian indikator perencanaan dan pengorganisasian (planning and organizing), selanjutnya pada dimensi functional competency indikator business process, dan indikator analitycal thinking dengan memberikan pengarahan dan pelatihan kepada pegawai yaitu dengan memberikan tugas dan pelatihan yang mengarah kepada pengembang kompetensi yang ditetapkan oleh organisasi.

b. Agar penilaian prestasi kerja pegawai dapat terarah dengan baik dan tepat sasaran perlu dilakukan perbaikan pada dimensi hasil kerja indikator kualitas kerja pegawai, dimensi kompetensi indikator mengenai pencapaian kompetensi core, role, dan functional, kemudian pada dimensi komitmen indikator komitmen pegawai pada organisasi, kemauan pegawai melakukan lembur di luar jam kerja normal, dan keadaan rasa bangga terhadap organisasi, pada dimensi tugas tambahan indikator respon pegawai, dampak pemberian tugas tambahan, serta tanggung jawab pegawai dengan cara melakukan pengawasa penuh kepada pegawai dalam melaksanakan tugasnya, mengontrol kinerja pegawai dengan memberikan arahan secara langsung, memberikan tugas baru yang bersifat membangun semangat bekerja pegawai dan peningkatan produktifitas kinerja pegawai.

c. Agar promosi jabatan dapat berjalan dengan lancar dan berjalan sesuai dengan peraturan yang berlaku, maka perlu dilakukan peningkatan hasil kerja pegawai menjadi lebih baik, meningkatkan keterampilan pegawai, memberikan pengalaman bekerja yang lebih banyak pada pegawai, memberikan pelatihan agar pegawai dapat menguasai bidak pekerjaanya, meningkatkan disiplin pegawai sesuai denga peraturan dan kode etik yang berlaku, dan memberikan kesempatan meningkatkan kualitas pendidikan yang dimiliki oleh pegawai untuk menjamin masa depat karir pegawai kedepannya.

d. Dari semua usaha yang dilakukan penulis dalam penelitian ini masih banyak kelemahankelemahan yang belum dapat diungkapkan pada seluruh variabel yang mempengaruhi promosi jabatan pada Badan Penyelenggara Jaminan Sosial (BPJS) Kesehatan Cabang
Pematangsiantara. Penulis berharap kedepannya, penelitian ini dapat menjadi masukan pada penelitian selanjutnya, dan perlu memperbaikinya variabel peneltian selanjutnya.

\section{E. DAFTAR PUSTAKA}

BPJS Kesehatan. 2010. Sistem Manajemen Kinerja Pegawai Berbasis Kompetensi (SMKPBK). Jakarta : PT. Askes (Persero)

Dessler, R. L. 2007. Manajemen Sumber Daya Manusia. Edisi 10. Jilid 1. Jakarta : Penerbit Salemba Empat.

Gomes, Faustino Cardoso. 2003. Manajemen Sumber Daya Manusia. Yogjakarta : Penerbit Andi.

Mangkunegara, Anwar Prabu. 2000. Manajemen Sumber Daya Manusia Perusahaan. Bandung : Penerbit Remaja Rosdakarya.

Mangkunegara, Anwar Prabu. 2005. Evaluasi Kinerja SDM. Bandung : Penerbit Refika Aditama

Mathis, Robert L. dan John H. Jackson. 2006. Human Resources Management (Manajemen Sumber Daya Manusia). Edisi Sepuluh. Jakarta: Penerbit Salemba Empat.

Mondy, R Wayne. 2008. Manajemen Sumber Daya Manusia. Edisi Kesepuluh, Jilid 1, Jakarta : Penerbit Erlangga.

2008. Manajemen Sumber Daya Manusia, Edisi Kesepuluh, Jilid 2, Jakarta : Penerbit Erlangga.

Panggabean, Mutiara S. 2002. Manajemen Sumber Daya Manusia. Cetakan Pertama. Bogor : Ghalia Indonesia.

Siagian, P. Sondang. 2006. Manajemen Sumber Daya Manusia. Cetakan Kedua. Jakarta : Penerbit PT. Bumi Aksara.

2009. Manajemen Sumber Daya Manusia Edisi Ketiga. Jakarta : Penerbit PT. Bumi Aksara.

Sudarmanto. 2009. Kinerja dan Pengembangan Kompetensi SDM. Cetakan Pertama. Yogjakarta : Pustaka Belajar.

Sutrisno, H. Edy. 2012. Manajemen Sumber Daya Manusia. Edisi Pertama. Cetakan Ketiga. Jakarta : Kencana.

Wahyudi, Bambang. 2002. Manajemen Sumber Daya Manusia. Edisi Revisi. Bandung : Sulita. 